\title{
Redaksjonelt
}

\section{Med kunstfagene inn i et nytt tiår}

Redaksjonen i ADNO er glade for å kunne presentere tre artikler som representerer kunstfagene innen lærerutdanning og grunnskole, to artikler innenfor musikk og en artikkel innen kunst og håndverk. Gjennom å løfte fram det praktisk-estetiske fagfeltet, utvider vi nå det brede fagdidaktiske feltet som ADNO ønsker å representere.

Ragnhild Elisabeth Lund (Høgskolen i Vestfold) belyser i sin artikkel "I sangen møtes vi på felles grunn - om sang og sangbøker i norsk skole” hvordan sangbøker har fungert som et læremiddel i mer enn 150 år i Norge. Artikkelen belyser sangfagets begrunnelser basert på skolehistoriske tekster og læreplaner fra det tidlige 1800-tallet og fram til vår tid. Lund har kartlagt repertoarvalg fra tolv sangbokverk, fra 1850 (Behrens' Skolesangbog) til 2008 (Amsrud \& Bjørnstads Sang i Norge). Med referanse til en definisjon av kanon som "stabile forekomster" identifiserer artikkelen 34 sanger som kan sies å utgjøre en del av "den norske sangskatten”. Tematisk har denne artikkelen paralleller til vår neste artikkel innen musikkfaget. Odd Magne Bøe (Høgskolen i Sør-Trøndelag) har skrevet artikkelen "Vi har musikk i skolen for å bli bedre til å synge! Elevens egen stemme om sangaktiviteten i skolens musikkopplæring". Artikkelen fokuserer på sangaktivitet slik det gis rammer for i "Læreplanverket for Kunnskapsløftet” (LK06). Bøe presenterer en empirisk studie basert på 64 gruppeintervjuer av til sammen 275 elever på 2., 4., 7. og 10. trinn ved 11 ulike skoler $\mathrm{i}$ Trondheimsregionen. Intervjuene fant sted over en periode på tre år (2006 2009), og fokuserer på elevenes egne erfaringer, ønsker og drømmer i forbindelse med sangaktiviteter. Med henvisning til Eide (2003), skriver Bøe om hvordan det har vært lite aktuelt å spørre barn om å vurdere sider ved deres egen oppvekst og læringssituasjon. Bøe sin artikkel representerer derfor et viktig bidrag, ikke bare for musikkfaget, men også for utdanningsforskning generelt, ved å la elevenes stemmer bli hørt.

I artikkelen ”Arbeidsformer i faglærerutdanningen i formgiving kunst og håndverk - en introduserende og kvantitativ studie av studentenes erfaringer" presenterer Marte Sørebø Gulliksen (Høgskolen i Telemark) og Finn Hjardemaal (Universitetet i Oslo) resultater fra første del i et større forskningsprosjekt. Forskerne søker svar på hvilke arbeidsformer som empirisk sett forekommer i institusjonens studium. Den første delen av forskningsprosjektet baseres på analyser av ramme-, fag- og emneplaner og et kvantitativt materiale om faglærerutdanningen i kunst og håndverk innhentet som en del av den store StudData undersøkelsen til Senter for profesjonsforskning ved HiO.

Resultatene fra analysen peker på at fagplanene ser ut til å vektlegge studentenes individuelle kompetansebygging og ha et fokus på individuelle 
arbeidsformer, mens studentene selv rapporterer at utdanningen i større grad har hovedfokus på det kollektive aspektet. Forfatterne ser på spenningsforholdet mellom den formelle og den erfarte læreplanen, noe som drøftes i lys av didaktiske spørsmål i perspektiv fra Goodlad (1979) til Gundem (1998) og Engelsen (2006).

Med tanke på at faglærerutdanningen i formgiving, kunst og håndverk nå møter de samme krav om å være forskningsbasert som andre universitets- og høgskoleutdanninger, har Gulliksen og Hjardemaal her gitt et viktig bidrag til forskningsfeltet.

Glenn Ole Hellekjær (Universitetet i Oslo), har anmeldt François Grin, Claudio Sfreddo \& François Villancourts nye bok: The Economics of the Multilingual Workplace. Dette er en bok som i følge anmelderen ligger i skjæringspunktet mellom anvendt lingvistikk og sosialøkonomi. Med data fra Sveits og Canada har forfatterne utviklet en økonomisk modell for å beregne hvordan språkkunnskaper bidrar til produksjonen av varer og tjenester. Hellekjær skriver at forfatterne både presenterer lingvistiske tilnærmingsmåter til språkbruk i arbeidslivet, så vel som drøfting av fordelene med flerspråklighet i forskningen og arbeidslivet for øvrig. I en tid hvor det med rette har vært fokusert mye på realfag, er det interessant å kunne løfte fram bøker som også ser på viktigheten av økt fokus på fremmedspråk.

Så langt i 2010 har ADNO publisert 8 artikler, og en bokomtale. Redaksjonen ønsker å takke alle fagkonsulentene våre som har bidratt til å sikre kvaliteten til tidsskriftet.

På slutten av året er det også en glede å få ønske professor Erik Knain, Universitetet for miljø- og biovitenskap (UMB) velkommen inn i redaksjonen. Knain har sittet i redaksjonsrådet siden oppstarten av ADNO i 2007, og vil nå tre inn som seksjonsredaktør i tidsskriftet. Avslutningsvis benytter jeg anledningen til å takke for meg, etter å ha vært ansvarlig redaktør fra 1. august 2010. En spesiell takk til redaksjonsleder og øvrige redaksjonsmedlemmer som har vært gode støttespillere i denne perioden. Nå overtar Jon Magne Vestøl igjen som ansvarlig redaktør og vi ønsker ham og redaksjonen lykke til med nye publiseringer for ADNO i 2011.

Oslo, desember 2010

Therese Nerheim Hopfenbeck

Ansvarlig redaktør (vikar) 